\title{
研究連絡委員会の活動から
}

日本学術会議では、第18期活動計画（本誌2000年12月号11ページ参照）に基づく審 議を各委員会が行うほか、シンポジウム等の開催を行っています。

今回は、各研究連絡委員会および専門委員会の活動を、すでに開催されたシンポジ ウム等の開催の状況を交えて紹介いたします。

\section{生命力が枯渇しない 都市をめざして}

—21世紀の都市と都市計画の展望—

— 社会環境工学研連都市地域計画専門委員会の活動から—

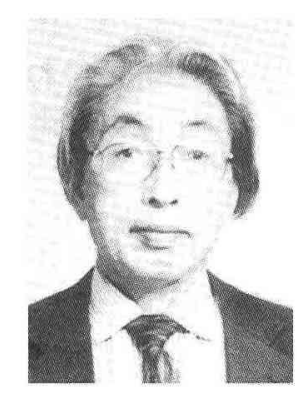

高野 公男

\section{世紀末の都市計画シンポジウム}

21世紀には都市はどのような様相を呈するの であろうか。また、どのような都市を目指せば よいのか。都市地域計画専門委員会では、今後 の都市や地域づくりのあり方を探るために、平 成10年度より 3 回にわたる学際的なシンポジウ ムを開催している。

20 世紀という時代が終わろうとしている節目 の時期に、都市のあり方を根本的なところから 見直し、都市計画の方向と課題を探ることが本 シンポジゥムの意罒するところだった。21世紀 の都市を展望するためには、20世紀の都市と都 市計画を俯瞰的に点検するとともに、都市や社 会の動向を幅広く探り、課題を明確にしていか ねばならない。
そこで今回は、都市に関わりのある様々な分 野から、新しい情報の提供と都市計画を触発す る提言をいただき、それをもとに今後のあり方 を考えるというアプローチをとった。シンポジ ウムで取り上げたテーマ、講演者などプログラ ムの概要は、別記の通りである。3回のシンポジ ウムを通して参加いただいた伊藤滋慶應義塾大 学客員教授 (日本学術会議第17期会員)をはじ め、12人の専門家の提言は、21世紀の都市を展 望し、今後の都市計画のあり方を探る上で大変 有意義なものとなった。

ここでは、各講演者から提示いただいた様々 な角度からの示唆と提言、討議をとりまとめ、 私見も交えて報告するものである。 


\section{文明化と都市の行方}

20世紀はどんな時代だったのか。シ ンポジウム全体を通しての共通認識は、 以下のように要約される。それは、文 明の進むスピードが速く、社会変化や 環境変化が地球規模で進んだ激動の時 代だった。20世紀後半の、エネルギー 革命、住宅革命、流通革命、モータリ ゼーション、情報革命による文明化の 波は、人々の暮らし方や生活環境の姿 を大きく変えてきており、都市や農村 はもはや従来の概念では捉えられない 状況を示している。

「生活の近代化」を社会目標とし、「成 長」と「効率」、「便利さ」を社会原理 とした 50 年の社会展開は、大量生産・ 大量消費社会を招来し、未曾有の物質 的な豊かさをもたらしたが、その一方 で、自然環境の破壊、環境の均質化、 居住人口構成のアンバランス、都市の 砂漠化などの社会的ひずみも生み出し た。

地球環境問題をはじめ、効率優先の 都市構造、資源浪費型の暮らし方では いずれ立ちいかなくなるだろうという 危機感がすでに広く認識されてきてい
日本学術会議・都市地域計画シンポジウム・ テーマと講演者

第1回シンポジウム「世紀末の都市計画」

平成10年16日（金）、日本学術会議大講堂

問題提起 : 世紀末とは何か、20世紀都市計画を検証する

伊藤滋 (慶應義塾大学教授・日本学術会議会員・都市計画)

都市と宗教 : 都市は心の住まう所をどのように育ててきたのか 平成10年16日 (金)、日本学術会議大講堂

都市と宗教 : 都市は心の住まう所をどのように育ててきたのか 伊藤滋 (慶應義塾大学教授・日本学術会議会員・都市計画)

都市と宗教 : 都市は心の住まう所をどのように育ててきたのか 森谷正規 (放送大学教授・技術評論家)

都市と宗教 : 都市は心の住まう所をどのように育ててきたのか 横張真(筑波大学助教授・農村計画)

都市と宗教 : 都市は心の住まう所をどのように育ててきたのか 山折哲雄 (白鳳女子短期大学学長·宗教学)

都市と市民 : 都市の主役である市民とは誰か 御欴貴 (東京都立大学法学部教授·政治学)

討論：20世紀都市計画を検証する コーディネーター:石川幹子(慶應義熟大学教授・本専門委員会委員)

第2回シンポジウム「世紀末から新世紀へ」

平成11年11月9日 (火)、日本学術会議大講堂

問題提起:21世紀の都市計画を確立するための課題は何か 伊藤滋 (慶應義塾大学教授・日本学術会議会員・都市計画)

都市と文明:都市は自らの姿をどう描くか 井尻千男 (拓殖大学日本文化研究所長·文明論)

都市と虚実:中心と周緑による都市空間の形成 山口昌男 (札幌大学学長:文化人類学)

都市と情報:情報メディアによる電子ネットワーク社会の到来 西垣通 (東京大学社会科学研究所教授:システム工学)

都市と環境: 持続可能な都市のありようとは

中村桂子 (JT生命誌研究館副館長:生命科学)

討論:21世紀の都市計画を確立するには コーディネーター:村橋正武 (立命館大学教授・本専門委員会委員)

第3回シシポジウム「21世紀の都市を展望する都市と都市計画」 平成12年6月23日 (金)、日本学術会議大講堂

問題提起 : 21世紀都市計画への視座 伊藤滋 (慶應義塾大学教授・日本学術会議会員・都市計画)

都市と資源・エネルギー:「有限な地球という惑星の中での持続とは」 山地憲治 (東京大学大学院教授、エネルギー・環境政策)

都市の経済・文化 : 大采消費社会の都市文化の行方 端信行 (国立民族学博物館教授、経済人類学)

都市と心の病 : 都市という社会に心の救いはあるのだろうか 香山リカ (神戸芸術工科大学教授、精神病理学)

都市の生活景 : 人々は都市でどう暮らしていきたいのだろうか 大林宣彦 (映画監督)

討論：21世紀の都市像をめぐって コーディネーター:篠原 修(東京大学教授・本専門委員会委員)

○総合司会・総括 (3回共通、本尃門委員会委員) 高野公男（東北芸術工科大学教授）、高見沢邦郎（東京都立大教授）、 大西隆 (東京大学教授)

(主催) 日本学術会議社会環境工学研究連絡委員会・都市地域計画専門委 員会、農村計画学研究連絡委員会・地域計画専門委員会

(共催) 日本都市計画学会、日本建築学会、土木学会、日本造園学会、 農村計画学会 都市住宅学会

(協賛) (財) 都市防災研究所 (第1回)、(財) 社会安全研究財団 (第2、3回)

（※肩書きは当時） 
る。一方、グローバリゼーション、ボーダレス 化の進行とともに加速化する情報革命や流通革 命は、さらに都市や社会の姿、人々の暮らし方 を大きくを変える力として働いている。これら の文明化は、都市の利便や物質的な豊かさをも たらす可能性はあるだろう。

しかし、文化の連続性を断ち、従来の都市や 共同体を解体する可能性のある文明化の波を無 批判に受け入れていくことは、都市に重大な危 機をもたらし、将来に禍根を残すことにはなら ないかという危惧もある。個性を失い、実在感 が希薄化し、人間が生き生きしない都市は、は たして真の幸福をもたらすものであろうか。新 しい文明化の波の中で都市計画のあり方が問わ れている。「限りない成長」という共同幻想が崩 れたいま、従来の近代合理主義に代わる価值観、 新しい都市づくりの理念と目標がまさに真剣に 探し求められているのである。

\section{機械論的世界観から生命論的世界観へ}

21世紀はどんな社会原理で進めばよいのか。 様々な提言をいただいたが、パラダイムの転換 という点から中村桂子氏の「機械論的世界観か ら生命論的世界観へ」という提言が共感を呼び、 包括的で示唆深かったのでここで紹介してみたい。 中村氏は、20世紀の都市づくりを進めたその 根底にある世界観は「機械論的世界観」ではな
かったかとする。しかし、人間が生活する社会 は生命の世界であり、都市や社会を機械として みる世界観に依拠しては望ましい社会や環境を つくっていくことはできない。生命論から都市 を捉え直すことは、「人間が生き物であることを 認識し、人間の生命起源以来の原初的感覚を呼 び覚まし、共生や循環という自然撕理、全体性 の中で生存環境のあり方を考えること」である と論じた。

そして、そのエッセンシャルな考え方を、「進 歩」 $\rightarrow$ 「進化」、「効率」 $\rightarrow$ 「過程」、「均一」 $\rightarrow$ $\lceil$ 多様」、「機能」 $\rightarrow$ 「関係」、「部分」 $\rightarrow$ 「全体」、 と機械論的世界観と対置して示し、そして、「効 率」と「人工」に偏っていた都市計画の論理に 「自然」と「ゆとり」の2軸を加え、バランスの よい全方位の都市づくりを目指すべきであると 提案した。

都市計画の分野は、その成り立ちから政策科 学と建設工学という2つの側面をもつが、「工学」 という既成の概念の制約も手伝って、狭い範囲 の技術的合理性、機械論的な発想に偏って都市 をとらえる側面があったことは否めない。また 各分野の技術論理がその専門分化した狭い世界 で「たこ壶的」に展開したために、社会全体と の関係性を見失ってしまっていた感もある。こ のような生命論からの発想は、これからの都市 の計画論を構築するための有力な手がかりとし 
て注目していく必要があるだろう。

\section{1 世紀の都市計画の方向}

都市計画は、いつの時代においても社会計画 の空間化という役割を担っている。そして、現 実の都市問題への対応と理想社会の実現という2 つの命題を抱えている。この都市計画の役割は 21世紀になっても変わらないだろう。理想社会 とは何かという問いかけは常にあるけれども、 理想社会のイメージは、人間や人間社会の本質 的な探求を基に生まれてくるものであろう。

今回のシンポジゥムでは、各分野の識者から 都市の本質に迫る貴重な提言をいただいたが、 その提言に共通するイメージは「自然との共生」 や「人間が生き生きと暮らす社会」であり、そ の根底にあるキーワードは「有限の地球」と 「生命」であった。20世紀の中葉に、サイバネテ イックス (人間機械論) などの機械論的な世界観 が生まれ、その思想が20世紀後半の工業化社会 をリードしたが、21世紀には中村氏の提唱する ような生命論的世界観が主導原理となっていく のではないだろうか。

人類の歴史を踏まえれば、社会の進化によっ て都市計画の根本原理が、神 (古代) から人間へ (中世〜近世)、人間から機械へ（近代一現代）、 機械から生命へ(現代一未来)、と移行している ということになる。
21世紀は、人間の生命力が枯渴しない都市づ くりをめざさねばならない。各識者からの様々 な角度からの示唆や提言をさらに掘りさげ、そ れを活かしていくことが、人間が、幸福になる 理想都市の実現に一歩近づくことになろう。そ して、持続可能な都市もこのような世界観の確 立をもとにしてこそ具現できるのではないだろ うか。21世紀の都市計画の扉を開くためには、 まず基本的な理念の確立が重要である。今回は、 個別的な都市問題について論ずることができな かったが、それは次のステップの課題として取 り組んでいきたい。

\section{注 記}

本シンポジウムの講演記録は以下の (財) 地域開発 センター機関誌に掲載されている。

・『特集 : 世紀末の都市計画 I -世紀末の都市計画』 「地域開発」、1999年5月号

・『特集：世紀末の都市計画II-世紀末から新世紀へ』 「地域開発」、2000年2月号

・『特集 : 21 世紀の都市を展望する-都市と都市計画』 「地域開発」、2000年11月号

高野 公男（たかの きみお 1936年生） 日本学術会議第17期社会環境工学研究連絡委員会都市地 域計画専門委員会委員長、東北芸術工科大学教授 専門：建築学・都市計画 